\title{
EVALUATING THE PERFORMANCE OF A LOCALLY COMBINE FOR HARVEST WHEAT CROP
}

\section{*Abo EL-Naga, M.H.M. **Shetawy.M.A. El-Said and ***Abed El-Hammed, Sh.F ABSTRACT}

Minimize of all harvest losses for wheat crop represent the important factor for upgrade harvest system The present study aimed to evaluate a locally combine for harvest wheat crop The experiments were carried out in Barkeen Village - Dakahlia Governorate during two seasons (2008 2009) for harvesting wheat crop (Sakha 93) at forward speed of 0.53, $0.70,0.95$ and $1.15 \mathrm{~km} / \mathrm{h}$, and at grain moisture contents of 16.73, 14.41 and $12.13 \%$ during standard drum speed of $24.74 \mathrm{~m} / \mathrm{s}$. The preharvesting losses for (sakha 93) $w$ as about $0.28 \%$ at grain moisture content of $12.13 \%$, straw moisture content of $25.73 \%$ and daily times of $12^{P M}$. While, the highest value of total grain losses $2.08 \%$ was obtained at forward speed of $1.15 \mathrm{~km} / \mathrm{h}$ and grain moisture content of $16.73 \%$.The highest performance efficiency of machine $98.91 \%$ was obtained at forward speed of $0.53 \mathrm{~km} / \mathrm{h}$ and grain moisture content of $12.13 \%$ While, the highest cutting efficiency $94.81 \%$ were obtained at forward speed of $0.53 \mathrm{~km} / \mathrm{h}$ and grain moisture content of $12.13 \%$.The highest effective field capacity and efficiency $(0.48 \mathrm{fed} ; / \mathrm{h}$ and $78.38 \%)$ were obtained at forward speed of $(1.15$ and $0.53 \mathrm{~km} / \mathrm{h})$ and grain moisture content of $12.13 \%$, respectively. Whereas .the lowest value of energy requirements $311.01 \mathrm{~kW} . \mathrm{h} / \mathrm{fed}$; was at forward speed af $1.15 \mathrm{~km} / \mathrm{h}$ and grain moisture content af $12.13 \%$, respectively. The lowest value of criterion cost 312.10 L.E / fed; were obtained at forward speed of $1.15 \mathrm{~km} / \mathrm{h}$ and grain moisture content of $12.13 \%$.

\section{INTRODUCTION}

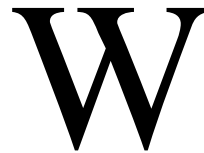

heat is the most important cereal crop in Egypt, it occupies about 2.75 millions feddan with a national average of about 2.28 tons, producing yearly about 6.27 millions tons of grain and 9.6558 millions tons of straw, Ministry of agriculture (2006) A.R.E. The advancement of wheat productivity A principal aim of promoting agricultural production and reduce import, and to help reduce

\footnotetext{
* Senior Researcher, Agric.Eng. Res. Inst., Dokki, EL- Giza, Egypt.

** Lect. Agric. Eng. Dept. Fac. of Agric., Al-Azhar Univ. Egypt.

*** Researcher,Agric. Eng. Res. Inst., Dokki, EL-Giza, Egypt
} 
the food gap in Egypt to achieve this requires minimization of total losses during the various stages of harvest methods, where previous studies have shown a big losses with different harvest systems and during harvest and to contribute to multi achieve the desired goal This is done using the techniques developed and the mechanism by which can minimize the total losses, and that the machine is one complete in the process of mowing, gathering and threshing and separation of straw and assemble the desired image to the Egyptian farmer in a separate tank. Therefore, a combine harvester is appealing solution to harvest wheat crop and save a harvest operation time, decreasing all losses and clearing the fields for the next crop. Tithes invest to be used as anew technology to overcome the high cost and losses traditional harvesting. Comberined with. Hassan et al (1994) found that, increasing forward speed to 1.2 $\mathrm{km} / \mathrm{h}$ at grain moisture content of $19.2 \%$ increased the header losses from $0.82 \%$ to $1.38 \%$ from $0.72 \%$ to $1.09 \%$ and from $0.22 \%$ to $0.87 \%$ when using Yanmer, Deatz and Fortshirt combines. respctively EL-Sayed et al; (2002) found that increasing forward speed from 1.7 to $2.7 \mathrm{~km} / \mathrm{h}$ the harvesting untreated, total losses and field capacity increased from 3.2; $1.95 ; 8.75 \%, 1.1 \mathrm{fed} ; / \mathrm{h}$ to $4.1,2.1,9.36 \%, 1.38 \mathrm{fed} ; / \mathrm{h}$, respectively and the damaged losses, performance efficiency decreased from 0.9 , and 94.06 $\%$ to $0.7,92.6 \%$, respectively. Too, at using wheat header in harvesting decreased total losses and criterion cost from $27,15 \%$ and 824 L.E / ton to $8.75 \%$ and increased 344 L.E/ton respectively. Also, the performance efficiency from $77.72 \%$ to $92.82 \%$ than using the corn header combine. Ebaid et al; (2004) found that, the optimum conditions of thresher machine to be operated at the maximum efficiency are; drum speed of 870 r.p.m., feed rate of $1200 \mathrm{~kg} / \mathrm{h}$, air speed at suction of $32 \mathrm{~m} / \mathrm{s}$, blower air speed of $6 \mathrm{~m} / \mathrm{s}$, sieve oscillation of 593 r.p.m, sieve tilt angle of 5 degrees and moisture content of $13.5 \%$ with machine purity of $99.30 \%$, fan losses of $0.11 \%$, losses behind sieve were found of zero \% .EL-khateeb(2005) found that the cylinder speed of $24.0 \mathrm{~m} / \mathrm{s}$ gave the minimum value of total losses $(2.33 \%)$ and maximum value of performance efficiency $(97.88 \%)$. baffle plate angles of $90^{\circ}(1.57 \mathrm{rad})$ gave the minimum values of cylinder loss, cleaning loss and total loss percentages $(0.70,0.55$ and $1.62 \%)$ and maximum value of performance efficiency of $97.95 \%$ by increasing the 
forward speed from 1.5 to $3.0 \mathrm{~km} / \mathrm{h}$. At grain moisture of $25.0 \%$ tends to decrease the rates of fuel consumption from 7.20 to $5.24 \mathrm{~L} / \mathrm{fed}$;. Imara et al.(2003) found that, the total grain losses increased by increasing the combine forward speed. The total grain losses of indirect harvesting method (using mower and threashing machine) increased about 2.5 times of that of total grain losses of direct harvesting (using combine). ELDanasory and Imbabi (1998) found that the baler losses of straw decreased by decreasing the forward speed and decreasing the period after harvesting with combine The actual capacity of baler was affected by the weight of straw yield and forward speed, the time requirement for picking up the straw of one feddan ranged from 0.9 to 1.7 hour using the baler. But it was 45.0 hours using the manual method. The cost of using baler to pick up and bating straw was nearly less than the half cost of manual method. The objective of this research is to determine the effect of forward speed, drum speed and grain moisture content on the total losses for a locally combine harvester.

\section{MATERIAL AND METHODS}

The experiments were carried out in Barkeen Village - Dakahlia Governorate during two seasons (2008 - 2009) for harvesting wheat crop (Sakha 93) by a locally combine harvester. It was fabricated in Kafr Sengap work shop - Dakahlia Governorate as shown in (Fig.1). The technical specification shown in table 1.

Table 1: Technical specifications of a locally combine harvester.

\begin{tabular}{|c|c|}
\hline \multicolumn{2}{|c|}{ Specifications of a locally combine harvester } \\
\hline \multicolumn{2}{|c|}{ Overall dimensions of combine: } \\
\hline length, cm & 475 \\
\hline width, $\mathrm{cm}$ & 300 \\
\hline height, cm & 325 \\
\hline \multicolumn{2}{|l|}{ The engine: } \\
\hline Type & $\begin{array}{l}\text { Diesel engine-vertical } 6 \text { cylinder-water } \\
\text { cooling }\end{array}$ \\
\hline Out- put ps /rpm & $125 / 3600$ \\
\hline Fuel tank capacity, 1 & 120 \\
\hline The power, $\mathrm{kW}$ & 104.53 \\
\hline Number of wheels & 10 \\
\hline Header section: & \\
\hline
\end{tabular}




\begin{tabular}{|l|l|}
\hline Working width, cm & 290 \\
\hline Pick-up and feed type & (Pick-up reel +auger) and elevator belt. \\
\hline
\end{tabular}

\section{Contin. Table 1}

\section{Threashing section:}

Type

Machine model.

locally wheat thresher

HMT/1987

\section{Overall dimension of threshing unit:}

\begin{tabular}{l|l}
\hline Length, cm & 235 \\
\hline Width, cm & 225 \\
\hline Height, cm & 175 \\
\hline Drum speed & $450-850 \mathrm{rpm}$ \\
\hline Feed type. & Mechanical feeding by elevator belt.
\end{tabular}

\section{Threshing drum:}

Type

Diameter, $\mathrm{cm}$

Length, cm

No. of rows

Knives

\section{The concave:}

Type

Concave perforations

Area of feeding gate, $\mathrm{cm}^{2}$

Area of straw gate out, $\mathrm{cm}^{2}$

\section{The sives:}

No.of hols $/ 100 \mathrm{~cm}^{2}$

Diameter of holes, $\mathrm{mm}$

\section{The fan:}

Type

No. of blade

\section{Straw container:}

Length, cm

Width, cm

Height, cm

Total volume, $\mathrm{m}^{3}$

Total capacity of straw yield, $\mathrm{kg}$. 


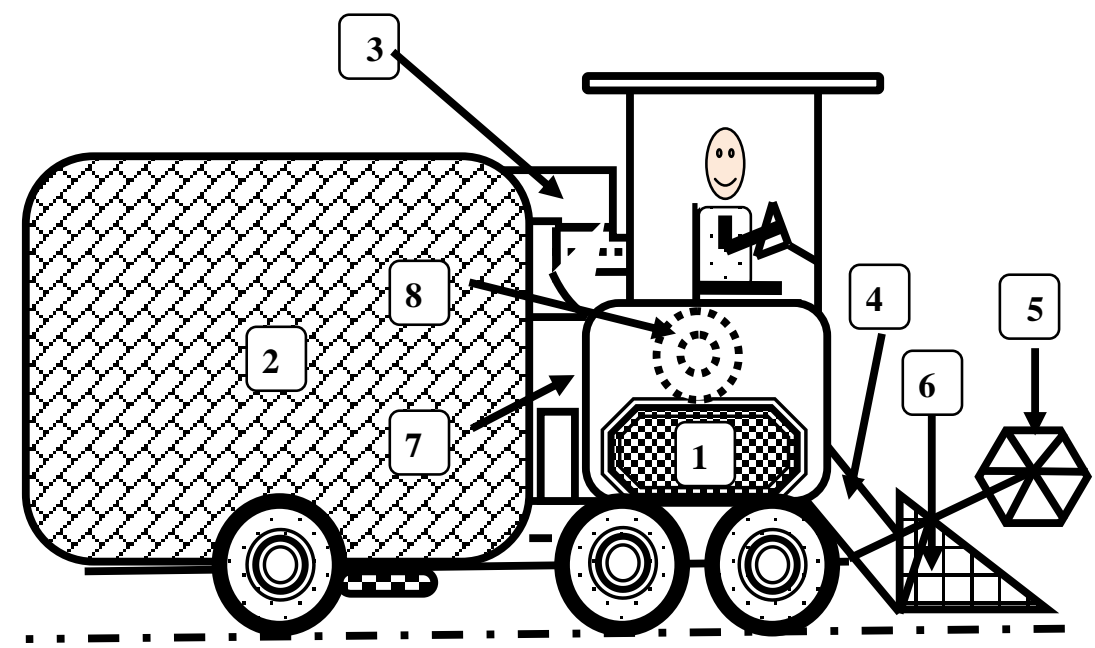

1- The engine

2- Straw container 3- Tube of straw output

4- Feeder conveyor

5- The reel

6- The header unit

7- Grain gate output 8- Threshing unit

Fig 1: The drawing line of a locally wheat harvester combine.
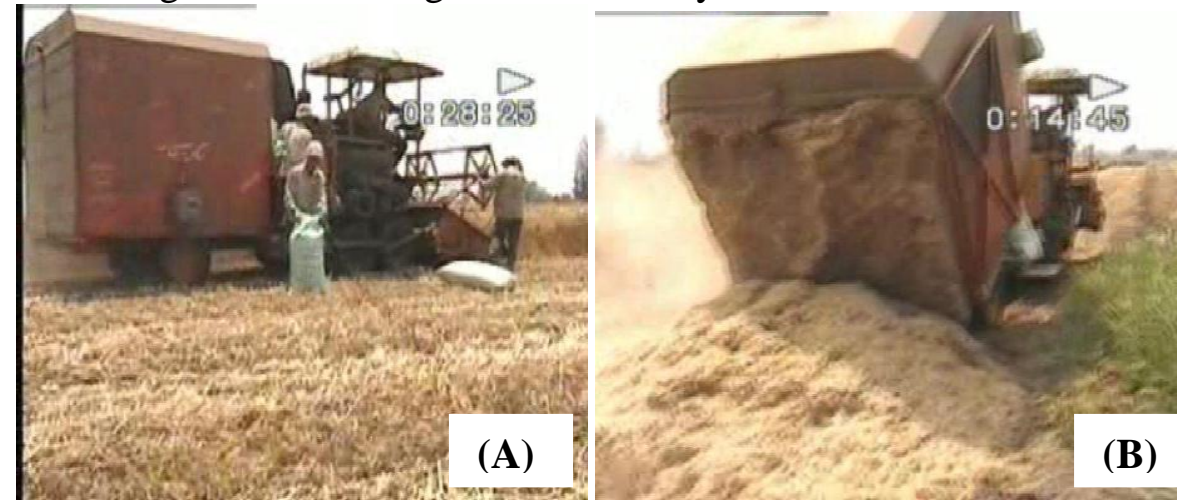

Fig.2:Photo of a locally drawing harvesting(A) and discharge straw(B)operation

The evaluation tested carried out under different forward speed of 0.53 , $0.70,0.95$ and $1.15 \mathrm{~km} / \mathrm{h}$, and grain moisture contents of $16.73,14.41$ and $12.13 \%$ at standard drum speed of $24.74 \mathrm{~m} / \mathrm{s}$.

\section{Measuring instruments:}

Balance, stopwatch, Electrical drying oven, tachometer, ruler, measure tape (50 meter) and wooden frame at dimension of $1 \mathrm{x} 1 \mathrm{~m}$ are useed to evalute the paramters.

\section{Measuring harvest losses;}

Pre-harvest losses. 
Pre-harvesting losses were determined by using a wooden frame at dimension of $1 \times 1 \mathrm{~m}$. It was put randomized through stand crop before harvesting to collect and weight the kernels found in the frame, this case replicated ten times. The percentage of pre-harvest losses was calculated by using the following equation;

(1) Pre - harvest losses $\%=\frac{\text { weight of grain collected }}{\text { total weight of yield }} \times 100$

\section{Header losses.}

After back the length of machine, put the wooden frame on the surface land in the front of machine within the harvested area. collect and weight the kernels found in the frame and subtract the weight the kernels found in the pre-harvest losses. The percentage of header loss was calculated by using the following equation;

(2) Header losses $\%=\frac{\text { Header losses } / \text { fed }}{\text { Total y ield/fed }} \times 100$

\section{Cutting efficiency:}

The cutting efficiency was calculated by using the following equation;

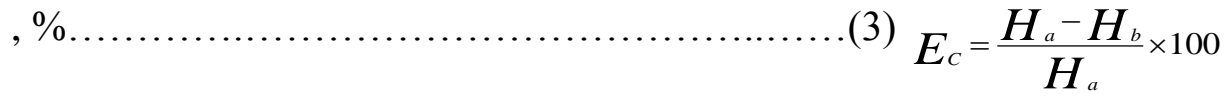

Where;

$\mathrm{H}_{\mathrm{a}}=$ height of stand plant above the soil surface before cutting, $\mathrm{cm}$.

$\mathrm{H}_{\mathrm{b}}=$ height of the stubble after cutting, $\mathrm{cm}$.

\section{Threshing losses.}

Threshing losses is a combine of many kinds of losses such as grain losses, grain damage and unthreshed grain. It can be calculated by using the following equation;

(4) Grain losses $\%=\frac{\text { mass of grain losses with thestraw/fed; }}{\text { Total mass of grain/fed; }} \times 100$

Grain damage $\%=\frac{\text { mass of grain damage/fed } ;}{\text { Total mass of grain } / \mathrm{fed} ;} \times 100$,

Unthreshed grain losses $\%=\frac{\text { mass of unthreshed grain } / f e d ;}{\text { Total mass of grain } / \mathrm{fed} ;} \times 100$,

Threshing efficiency $\%=\frac{\text { Threashinglosses } / \mathrm{fed} ;}{\mathrm{y} \text { ield/fed; }} \times 100$, 
Where;

Threshing losses $=$ (unthreshed grain losses + grain damage + grain losses $)$

\section{Combine performance efficiency.}

The combine performance was calculated by using the following equation:

Performanc efficiency, $\%=\frac{\text { output } / \text { fed; }}{\text { (output }+ \text { Total losses }) / f e d ;} \times 100$

Where;

Output $=$ amount of grain collected in the bin

Total losses $=$ (header losses + threshing losses)

Threshing losses $=$ (unthreshed grain losses + grain damage + grain losses)

The theoretical field capacity $\left(\mathbf{F c}_{\mathrm{th}}\right)$.

Field capacity, fed./ $h=\frac{\text { the width } \times \text { forward speed }}{\text { consant }}$,

$$
F c_{\text {th }}=\frac{w \times v}{4.2}
$$

Where:

$\mathrm{W}=$ theoretical machine width, $\mathrm{m}$,

$\mathrm{V}=$ machine travel speed, $\mathrm{km} / \mathrm{h}$.

The actual field capacity (Fcact).

$$
\text { (11) } F c_{a c}=\frac{60}{T u+T i}
$$

Where:

$\mathrm{Tu}=$ utilization time per feddan in minutes,

$\mathrm{Ti}=$ summation of lost time per feddan, in minutes

\section{Fuel consumption:}

It was determined by measuring the volume of fuel consumed during each operation.

\section{The Power and energy requirements}

The power consumed by each mechanized system for harvesting operations was calculated using the measured fuel consumption by the used combine during the operation. The following formula was used to 
estimate power consumption by the mechanized system according to Hunt (1983), and Rangasamy et al.(1993) as follows:

$$
P=\frac{F C}{3600} \times \rho . f \times L C V \times 427 \times \eta_{t h} \times \eta_{m e c} \times \frac{1}{75} \times \frac{1}{1.36} \ldots, k W
$$

Where:

$\mathrm{FC}=$ fuel consumption, $\mathrm{L} / \mathrm{h}$,

$\rho_{. \mathrm{f}}=$ density of fuel, $\mathrm{Kg} / \mathrm{L}$ (For diesel $\left.=0.85\right)$;

L.C.V= calorific value of fuel $(10000 \mathrm{kcal} / \mathrm{kg})$;

$427=$ thermo-mechanical equivalent, $\mathrm{J} / \mathrm{kcal}$,

$\eta_{\mathrm{th}}=$ thermal efficiency of engine $(\approx 35 \%$ for diesel engines $)$,

$\eta_{\text {mec }}=$ mechanical efficiency of engine $(\approx 80 \%)$.

While, the energy required for each mechanized system was estimated using the following equation: -

Energy requirements $(k W . h /$ fed. $)=\frac{\text { Power requirement }(k W)}{\text { Effective field capacity }(\text { fed } / h)}$,

Specific energy requirements (kW.h / ton), was calculated by multiplying the consumed power $(\mathrm{kW})$ dividing the machine productivity (ton) per houre.

\section{The operation system cost}

The hourly cost for machine operation was determined using the following equation, $\mathrm{Hunt}$, (1983)

Hourly cost $=\mathrm{P} / \mathrm{H}(1 / \mathrm{A}+\mathrm{I} / 2+\mathrm{T}+\mathrm{R})+(0.9 \mathrm{~W} . \mathrm{S} . \mathrm{F})+\mathrm{M} / 144$, .E. $/ \mathrm{h}, . .(14)$

Where:

$\mathrm{P}=$ price of machine, L.E, $\quad \mathrm{H}$ =yearly working hours, $\mathrm{h} /$ year,

$\mathrm{A}=$ life expected of machine, year, $\mathrm{I}=$ interest rate / year,

$\mathrm{T}=$ taxes, over heads ratio, $\quad \mathrm{R}=$ repairs and maintenance ration,

$0.9=$ factor accounting for lubrication $\mathrm{W}=$ power, $\mathrm{hp}$,

$\mathrm{S}=$ specific fuel consumption(L/hp.h), $\mathrm{F}=$ fuel price, L.E. / L,

$\mathrm{M} / 144$ = monthly wage ratio, L.E,

The operating cost per Fed was determined using the following equation:

Machinery..operating. $\cos t=\frac{\text { hourly } \cdot \cos t(\mathrm{LE} / \mathrm{fed} ;)}{\text { machine.actual. field ..capcity }(\mathrm{fed} / \mathrm{h})}$,

\section{The Criterion cost $(\mathrm{C})$}

It was calculated from the equation of; 
$\mathrm{C}=$ operation cost $/$ fed + transporting cost + product losses cost/fed, (16)

\section{RESULTS AND DISCUSSION}

Description a condition crop before harvest operation is an important factor in a performance machine and has a great effect on loss and final conditions of grain and straw yield. Some crop characteristic are include Table 2.

Table 2: Mean values of some characteristics of wheat crop(variety of Sakha93)

\begin{tabular}{|l|c|}
\hline Some characteristics of wheat crop & Mean values \\
\hline Plant height $(\mathrm{cm})$ & 106.42 \\
\hline Thousand grain mass $(\mathrm{g})$ & 45.76 \\
\hline Spike grain mass $(\mathrm{g})$ & 2.54 \\
\hline No of grain /spike & 55.73 \\
\hline No of spikes / m & 396.22 \\
\hline
\end{tabular}

\section{Pre-harvest loss:}

Pre-harvest loss affected by many factors such as grain and straw moisture content and daily times. The results in Table 3 indicated that the pre-harvest loss is decreased by increasing of grain and straw moisture content (w.b) Table 3. Pre-harvesting loss at different grain and straw moisture content.

\begin{tabular}{|c|c|c|c|}
\hline $\begin{array}{c}\text { Daily } \\
\text { times }\end{array}$ & $\begin{array}{c}\text { Straw moisture } \\
\text { content, } \%\end{array}$ & $\begin{array}{c}\text { Grain moisture } \\
\text { content, } \%\end{array}$ & $\begin{array}{c}\text { Pre-harvest } \\
\text { loss, } \%\end{array}$ \\
\hline $10^{\mathrm{AM}}$ & 31.28 & 16.73 & 0.13 \\
\hline $12^{\mathrm{PM}}$ & 25.73 & 12.13 & 0.28 \\
\hline $4^{\mathrm{PM}}$ & 30.82 & 14.41 & 0.19 \\
\hline
\end{tabular}

\section{Harvest Losses:}

\section{1) Header losses:}

Data in Fig. (3) indicated that increasing in forward speed caused to increase the header loss at different grain moisture content. That is trend to excessive load of wheat stems at cutter-bar. While the decrease of grain moisture content caused increase in header loss at different forward speed. However, the highest and lowest value of header loss (0.3 and $0.12 \%)$ were obtained at forward speed of $(1.15$ and $0.53 \mathrm{~km} / \mathrm{h})$ and grain moisture content of (12.13 and16.73\%), respectively.

\section{2) Threshing losses:}

\section{A. Grain damage:}


Data in Fig. (4) referred that the increase in forward speed caused a decrease in grain damage that is due to excessive load in threshing unit, while the decrease in grain moisture content cased increase in the grain damage. That is due to wheat grain at low moisture content have a good chance to crashes and be broken by drum knifes. However, The highest and the lowest value of grain damaged $(0.24$ and $0.09 \%)$ were obtained at forward speed of $(0.53$ and $1.15 \mathrm{~km} / \mathrm{h}$.) and grain moisture content of (12.13 and $16.73 \%)$, respectively.

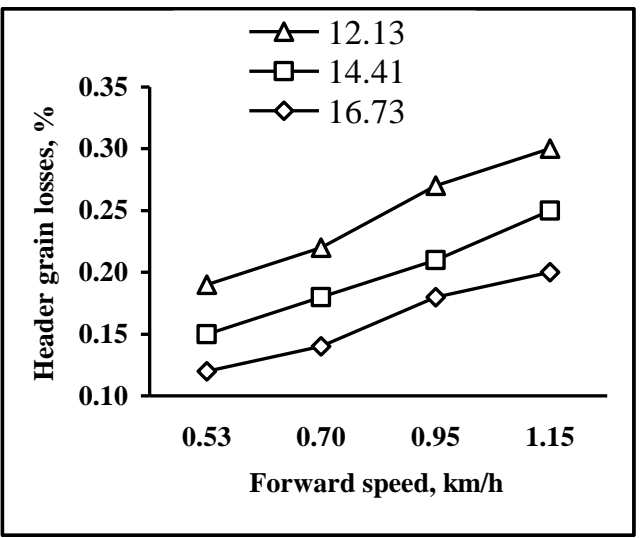

Fig 3: Effect of forward speed and grain moisture content on header losses.

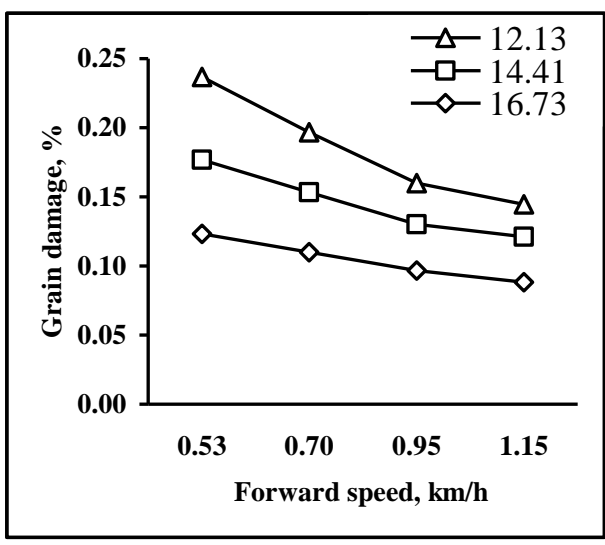

Fig.4:Effect of forward speed on grain damage at different grain moisture contents

\section{B. Unthreshed grains:}

Data in Fig.(5) showed that by increasing forward speed and grain moisture content caused. Increase in unthreshed grain. That is due to excessive load in threshing unit, while decrease in forward speed and grain moisture content caused a decrease in unthreshed grain. However, the highest and lowest value of unthreshed grain (1.34 and $0.26 \%$ ) were obtained at forward speed of $(1.15$ and $0.53 \mathrm{~km} / \mathrm{h})$ and grain moisture content of (16.73 and $12.13 \%)$, respectively.

\section{Threshing grain losses:}

Regarding to Fig. (6) evident that, increasing in forward speed caused to increase the threshing grain loss at different grain moisture content. While, the decrease in grain moisture content caused a decrease in threshing grain loss. However, the highest and lowest value of threshing grain loss $(0.76$ 
$\%$ and $0.15 \%)$ was obtained at forward speed of $(1.15$ and $0.53 \mathrm{~km} / \mathrm{h}$.) and grain moisture content of (12.13\% and 16.73), respectively.

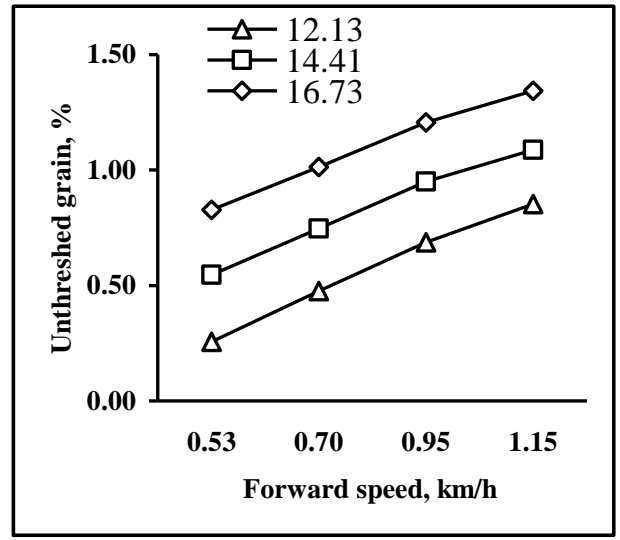

Fig. 5 : Effect of forward speed on unthreshed grain at different grain moisture contents.

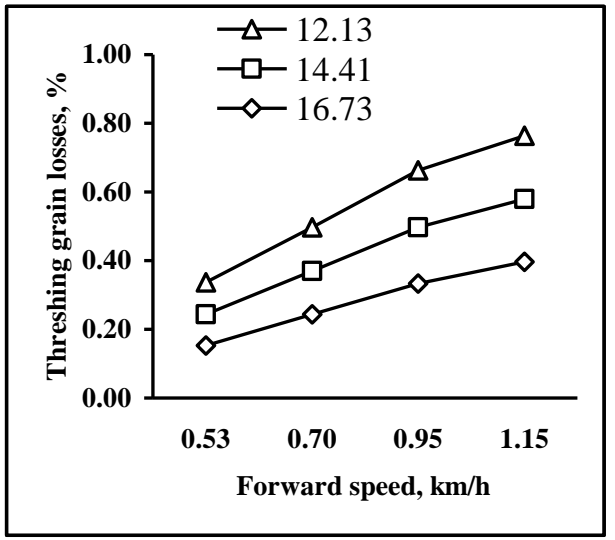

Fig. 6 : Effect of forward speed on grain losses at different grain moisture contents.

\section{Total threshing losses:}

Viewing to Fig. (7), it is clear that increasing in forward speed caused to increase in the total threshing loss, while the decreasing in grain moisture content caused a decrease the total threshing loss. However, the highest and lowest values of total threshing loss (1.83and $0.83 \%)$ were obtained at forward speed of (1.15 and $0.53 \mathrm{~km} / \mathrm{h})$ and grain moisture content of (16.7 and $12.13 \%)$, respectively.

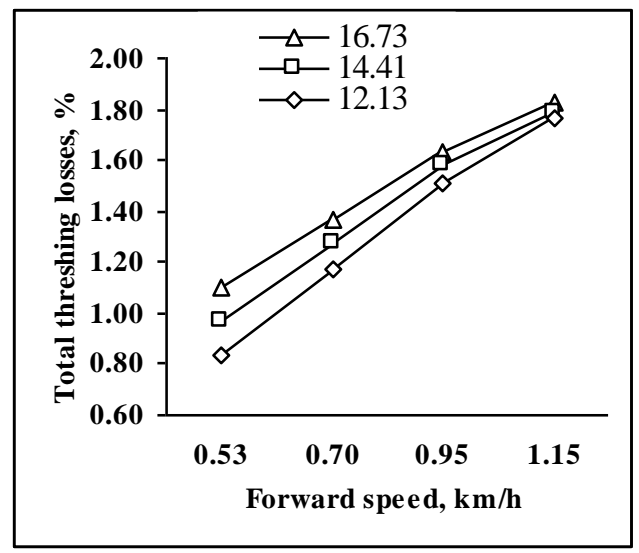

Fig. 7 : Effect of forward speed on total threshing losses at different seed moisture contents.

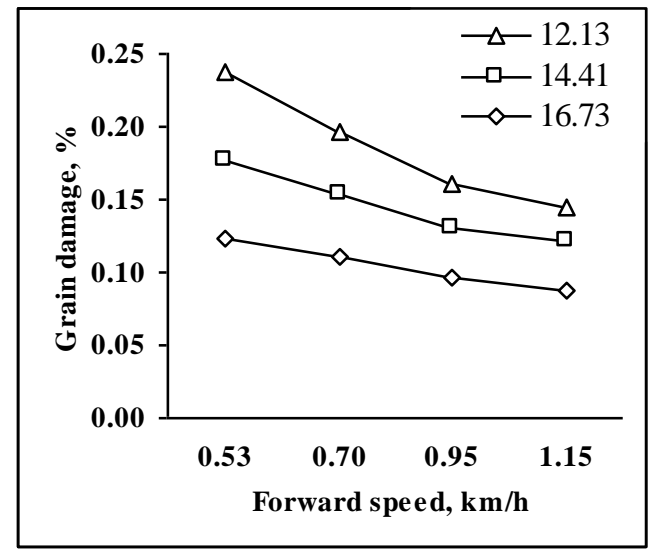

Fig. 8 : Effect of forward speed on total harvesting losses at different seed moisture contents. 


\section{Total harvesting losses:}

Viewing to Fig. (8); it is clear that increasing in forward speed and grain moisture content to caused increase in the total harvesting loss.

However, the highest and lowest values of total harvesting loss (2.08 and $1.17 \%$ ) were obtained at forward speed of (1.15and $0.53 \mathrm{~km} / \mathrm{h}$ ) and grain moisture content of (16.73 and 12.13\%); respectively.

\section{3) The performance efficiency:}

From Fig. (9) it is clear that increasing in forward speed tend to decrease and increase the performance efficiency of machine at different drum and forward speed and grain moisture content respectively. While, the decreased of grain moisture content tend to increase the performance efficiency of machine at the other factors. However, the highest and lowest value of performance efficiency of machine (98.91and $97.51 \%$ ) were obtained at forward speed of $(0.53$ and $1.15 \mathrm{~km} / \mathrm{h})$, and grain moisture content of (12.13 and 16.73\%), respectably.

\section{4) Cutting efficiency.}

From Fig. (10) It is clear that increasing of forward speed from 0.53 to $1.15 \mathrm{~km} / \mathrm{h}$ tend to decrease the cutting efficiency at different grain moisture content. This trend may be due to bending of stems under the cutter bar increases by increasing the forward speed.

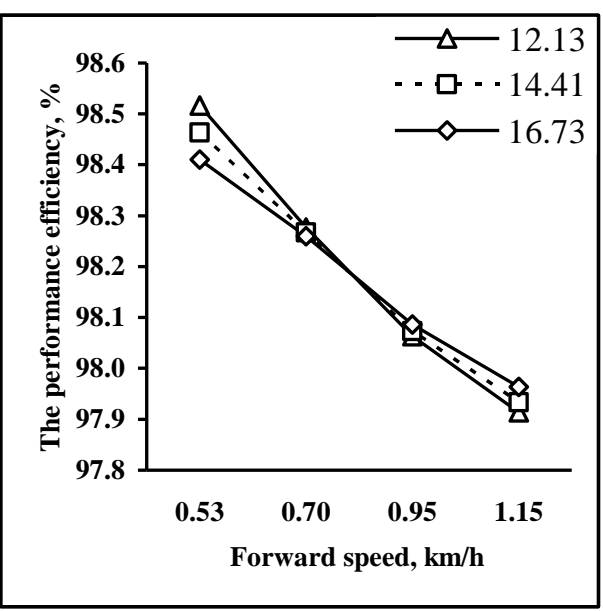

Fig. 9 : Effect of forward speed on combine efficiency at different seed moisture content.

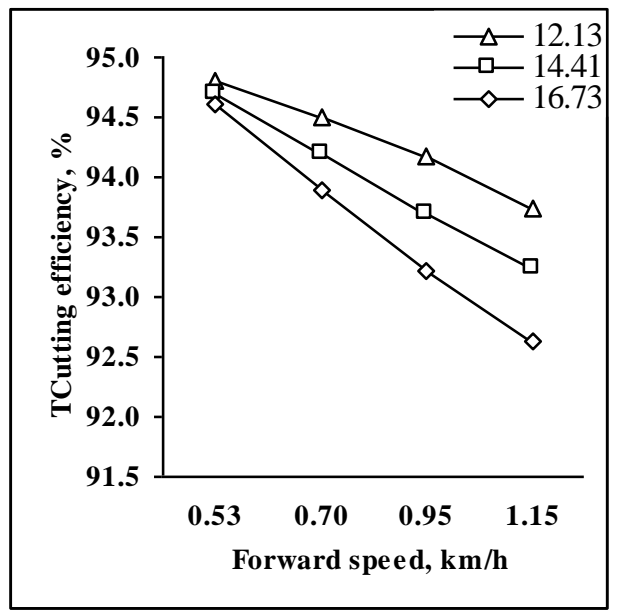

Fig. 10: Effect of forward speed on cutting efficiency at different grain moisture content. 
While, decreased of grain moisture content from 16.73 to $12.13 \%$ tend to increase the cutting efficiency at different forward speed. The highest and lowest value of cutting efficiency (94.81and 92.63\%) were obtained at forward speed of $(0.53$ and $1.15 \mathrm{~km} / \mathrm{h})$, and grain moisture content of (12.13 and $16.73 \%)$ respectively.

\section{5) Field capacity and efficiency:}

Data in Table (4) mentioned that the effective of field capacity increased at increase in forward speed and decreased in grain moisture content. While, the field efficiency decreased at increase in forward speed and grain moisture content. Whereas, the highest value of the effective field capacity and field efficiency $(0.48 \mathrm{fed} ; \mathrm{h}$ and $78.38 \%)$ were obtained at forward speed of $(1.15$ and $0.53 \mathrm{~km} / \mathrm{h})$ and grain moisture content of $12.13 \%$ respectively. While the lowest value of the effective field capacity and field efficiency ( $0.2 \mathrm{fed} ; \mathrm{h}$ and $48.01 \%)$ were obtained at forward speed of $(0.53$ and $1.15 \mathrm{~km} / \mathrm{h}$ ) and grain moisture content of $16.73 \%$, respectively.

\section{6) Energy requirements:}

Regarding to energy requirements data in Table(4) showed that the energy requirements decreased at increasing the forward speed and decreased in grain moisture content. However, the highest and lowest value of the energy requirements (693.08 and $311.01 \mathrm{~kW} . \mathrm{h} / \mathrm{fed}$;)

Table 4. Field capacity, field efficiency and energy requirements at different

forward speed and grain moisture content

\begin{tabular}{|c|c|c|c|c|c|c|}
\hline $\begin{array}{l}\text { Grain } \\
\text { moistur } \\
\text { content, } \\
\text { \% }\end{array}$ & $\begin{array}{c}\text { Forward } \\
\text { speed, } \\
\mathbf{k m} / \mathbf{h}\end{array}$ & $\begin{array}{c}\text { Actual } \\
\text { field } \\
\text { capacity } \\
\text { fed;/h }\end{array}$ & $\begin{array}{c}\text { Fuel } \\
\text { Consumpti } \\
\text { L/h }\end{array}$ & $\begin{array}{c}\text { Power } \\
\text { requirements } \\
\mathbf{k W}\end{array}$ & $\begin{array}{c}\text { Energy } \\
\text { requirements, } \\
\text { kW.h/fed; }\end{array}$ & $\begin{array}{c}\text { Field } \\
\text { efficiency } \\
\text { \% }\end{array}$ \\
\hline \multirow{4}{*}{$\mathbf{1 6 . 7 3}$} & $\mathbf{0 . 5 3}$ & 0.2 & 14.03 & 138.62 & 393.08 & 54.05 \\
\cline { 2 - 7 } & $\mathbf{0 . 7}$ & 0.25 & 14.97 & 147.90 & 591.61 & 52.08 \\
\cline { 2 - 7 } & $\mathbf{0 . 9 5}$ & 0.31 & 15.92 & 157.29 & 507.39 & 46.97 \\
\hline \multirow{4}{*}{$\mathbf{1 4 . 4 1}$} & $\mathbf{1 . 1 5}$ & 0.38 & 16.92 & 167.17 & 439.92 & 48.10 \\
\cline { 2 - 7 } & $\mathbf{0 . 5 3}$ & 0.25 & 13.41 & 132.49 & 529.96 & 67.57 \\
\cline { 2 - 7 } & $\mathbf{0 . 7}$ & 0.30 & 14.31 & 141.38 & 471.28 & 62.50 \\
\cline { 2 - 7 } & $\mathbf{0 . 9 5}$ & 0.36 & 15.2 & 150.18 & 417.16 & 54.55 \\
\hline \multirow{4}{*}{$\mathbf{1 . 1 5}$} & 0.43 & 16.17 & 159.76 & 371.53 & 54.43 \\
\cline { 2 - 7 } & $\mathbf{0 . 5 3}$ & 0.29 & 12.53 & 123.80 & 426.88 & 78.38 \\
\cline { 2 - 7 } & $\mathbf{0 . 7}$ & 0.34 & 13.37 & 132.10 & 388.52 & 70.83 \\
\cline { 2 - 7 } & $\mathbf{0 . 9 5}$ & 0.41 & 14.21 & 140.39 & 342.43 & 62.12 \\
\hline
\end{tabular}


were obtained at forward speed 0.53 and $1.15 \mathrm{~km} / \mathrm{h}$ and grain moisture content 16.73 and $12.13 \%$, respectively.

\section{Analyses cost:}

The operating cost affected directly by the grain output or productivity, Data in Table 5; indicated that increase in forward speed caused decreased in cost operation and criterion cost and increase in values of grain loss at different grain moisture content. However, the highest and lowest values of harvest operation cost (396.65and 174.02 L.E / fed;) were obtained at forward speed of $(0.53$ and $1.15 \mathrm{~km} / \mathrm{h}$ and grain moisture content of (16.73 and 12.13\%), respectively. While the highest and lowest values of criterion cost (494.67and 312.10 LE / fed;) were obtained at forward speed of $(0.53$ and $1.15 \mathrm{~km} / \mathrm{h}$ and grain moisture content of (16.73 and $12.13 \%)$, respectively. In addition the highest and lowest value of grain loss cost(149.31 and 80.19 LE/fed;)were obtained at forward speed of 1.15 and $0.53 \mathrm{~km} / \mathrm{h}$ and grain moisture content of(16.73and12.13\%) respectively

Table 5. Cost harvest operation and criterion cost for a locally combine of wheat harvesting

\begin{tabular}{|c|c|c|c|c|c|}
\hline $\begin{array}{c}\text { Grain } \\
\text { Moisture } \\
\text { content, } \\
\text { \% }\end{array}$ & $\begin{array}{c}\text { Forward } \\
\text { speed, } \\
\text { km/h }\end{array}$ & $\begin{array}{c}\text { Actual } \\
\text { Field } \\
\text { Capacity, } \\
\text { Fed;/h }\end{array}$ & $\begin{array}{c}\text { The cost } \\
\text { Operation, } \\
\text { L.E/fed; }\end{array}$ & $\begin{array}{c}\text { Values of } \\
\text { Grain losses, } \\
\text { L.E/fed; }\end{array}$ & $\begin{array}{c}\text { Criterion } \\
\text { Cost, } \\
\text { L.E/fed; }\end{array}$ \\
\cline { 2 - 6 } & $\mathbf{0 . 5 3}$ & 0.2 & 396.65 & 98.02 & 494.67 \\
\cline { 2 - 6 } & $\mathbf{0 . 7}$ & 0.25 & 320.32 & 117.39 & 437.71 \\
\cline { 2 - 6 } & $\mathbf{0 . 9 5}$ & 0.31 & 261.23 & 131.14 & 392.36 \\
\hline \multirow{3}{*}{$\mathbf{1 4 . 4 1}$} & $\mathbf{1 . 1 5}$ & 0.38 & 215.87 & 149.31 & 409.29 \\
\cline { 2 - 6 } & $\mathbf{0 . 5 3}$ & 0.25 & 320.32 & 88.97 & 409.29 \\
\cline { 2 - 6 } & $\mathbf{0 . 7}$ & 0.30 & 269.43 & 110.45 & 379.89 \\
\hline \multirow{3}{*}{$\mathbf{1 2 . 1 3}$} & $\mathbf{0 . 9 5}$ & 0.36 & 227.03 & 125.24 & 352.26 \\
\cline { 2 - 6 } & $\mathbf{0 . 5 3}$ & 0.43 & 192.51 & 142.98 & 335.50 \\
\cline { 2 - 6 } & $\mathbf{0 . 7}$ & 0.29 & 278.21 & 80.19 & 358.40 \\
\hline & $\mathbf{0 . 9 5}$ & 0.41 & 201.17 & 120.72 & 321.89 \\
\hline
\end{tabular}




\section{SUMMARY AND CONCLUSION}

Evaluation results of a locally combine harvester for wheat crop reveal to the following points:

- The highest value of header loss $0.3 \%$ was obtained at forward speed of $1.15 \mathrm{~km} / \mathrm{h}$ and grain moisture content of $12.13 \%$, respectively.

* The highest value of grain damaged $0.24 \%$ was obtained at forward speed of $0.53 \mathrm{~km} / \mathrm{h}$. and grain moisture content of $12.13 \%$, respectively.

* The highest value of unthreshed grain $1.34 \%$ was obtained at forward speed of $1.15 \mathrm{~km} / \mathrm{h}$ and grain moisture content of $16.73 \%$, respectively.

* The highest value of threshing grain loss $0.76 \%$ was obtained at forward speed of $1.15 \mathrm{~km} / \mathrm{h}$. and grain moisture content of $12.13 \%$, respectively.

* The highest value of total harvesting loss $2.08 \%$ was obtained at forward speed of $1.15 \mathrm{~km} / \mathrm{h}$ and grain moisture content of $16.73 \%$, respectively.

* The highest value of performance efficiency of machine $98.91 \%$ was obtained at forward speed of $0.53 \mathrm{~km} / \mathrm{h}$ and grain moisture content of $12.13 \%$, respectably.

* The highest value of cutting efficiency $94.81 \%$ was obtained at forward speed of $0.53 \mathrm{~km} / \mathrm{h}$ and grain moisture content of $12.13 \%$, respectively.

* The highest value of the effective field capacity and efficiency (0.48 fed;/h and $78.38 \%$ ) were obtained at forward speed of (1.15 and 0.53 $\mathrm{km} / \mathrm{h}$ ) and grain moisture content of $12.13 \%$, respectively.

* The highest and lowest value of the energy requirements (693.08 and $311.01 \mathrm{~kW} . \mathrm{h} / \mathrm{fed}$;) were obtained at forward speed 0.53 and $1.15 \mathrm{~km} / \mathrm{h}$ and grain moisture content 16.73 and $12.13 \%$, respectively.

* The highest and lowest value of harvest operation cost (396.65and 174.02 L.E / fed;) were obtained at forward speed of ( 0.53 and 1.15 $\mathrm{km} / \mathrm{h}$ and grain moisture content of (16.73 and 12.13\%) respectively.

The highest and lowest values of criterion cost (494.67and 312.10 L.E / fed;) were obtained at forward speed of $(0.53$ and $1.15 \mathrm{~km} / \mathrm{h}$ and grain moisture content of (16.73 and $12.13 \%)$ respectively. 


\section{RECOMMENDATION}

From the experimentally results, the best performance of a locally harvester combine obtained at forward speed of $0.53 \mathrm{~km} / \mathrm{h}$ and grain moisture content of $12.13 \%$ for harvesting wheat crop. Adding to, using a locally harvester combine for harvesting wheat, save many steps was achieved in a traditional method such as cutting, gathering, collecting, transporting, threshing operations and save a haulm crop. At the other hand, reduce the pollutions and save a good health to Egyptians farmers.

\section{REFERENCES}

Ebaid M. T.; A. A. Abd EL-Rahman; G. G. Radwan and H.E.Osman(2004). Development a threasher for wheat crop of beater type for maximum productivity Misr J. Agr. Eng., 21 (1): 1428.

EL-Danasory M. M. and A. T. Imbabi(1998). Study on mechanical and manual pick up and Baling of wheat straw after harvesting with combine. Misr J. Agr. Eng., 15(2): 246-260.

EL-Khateeb, H. A. (2005). A study on performance of axial flow combine harvester in rice crop harvesting. The $13^{\text {th }}$ conference of the Misr Society of Agr. Eng., 14-15 December 2005:381-401.

EL-Sayed G. H.; M. A. EL-Ataar and E. M. Arif (2002). Mechanical harvesting of sun flower using the general purpose combine. The $10^{\text {th }}$ annual conference of the Misr of Agr Eng,16-17 October2002:155-172

Hassan, M.A.; M. M. Morad; M. A. EL-Shazly and A.Farag(1994). Study on some operating parameters affecting the performance of combine devices with reference to grain losses. Misr J. Agric. Eng., 11(3): 767-780.

Hunt, D, (1983). Farm power and machinery management 8 th Ed., Iowa state Univ., Ames, U. S. A.

Imara Z. M.;Kh. A. A. Khadr; W. M. Mechail and A. O. M. Arif (2003). Effect of different planting and harvesting methods on wheat production Misr J. Agr. Eng. 20(1): 115-128. 


\section{الملخص العربي \\ تقييم أداء الة حصاد مجمعة محليا لمحصول القمح}

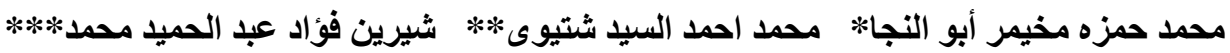

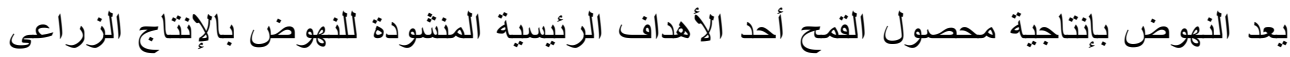
و تقليل إستير اده و المساهمة فى تقليل الفجوة الغذائية فى مصرولتحقيق ذلك يتطلب تدنية الفو اقد الكلية

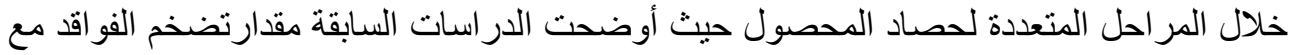

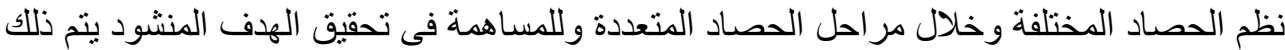

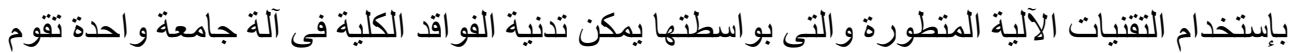

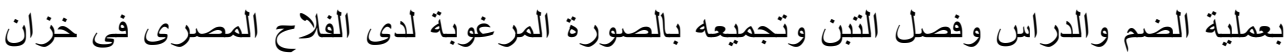

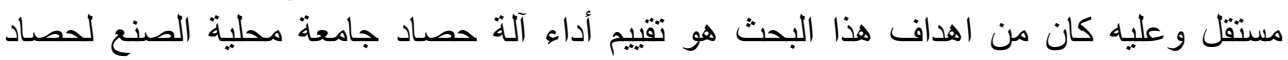

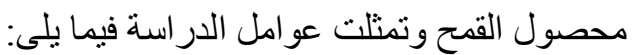

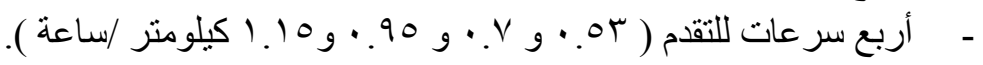

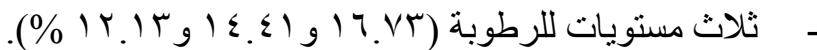

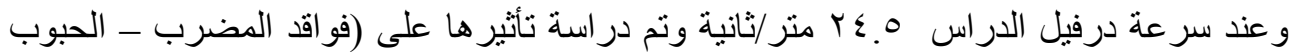

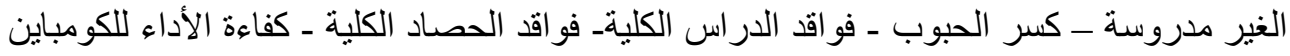

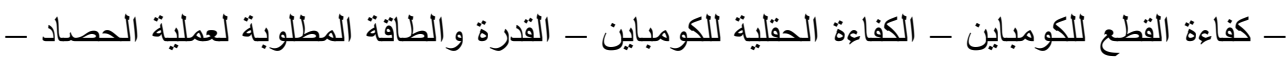
التكاليف الكلية).

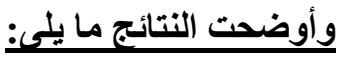

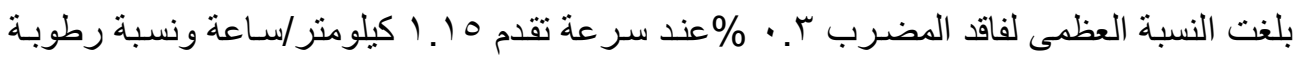
$\%$ \% I I

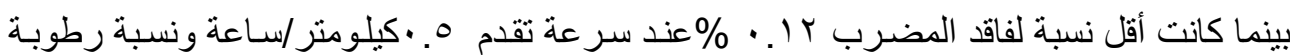
\%) T.V

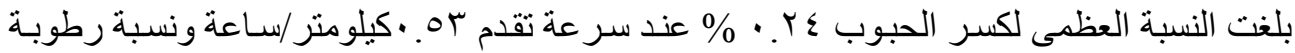

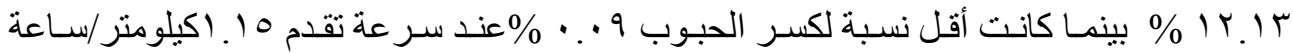

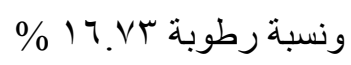

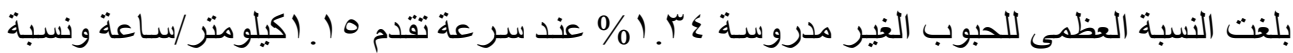

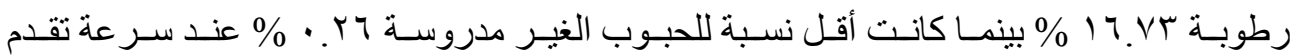

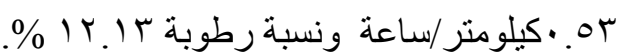

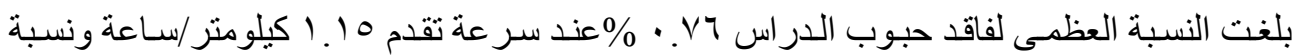

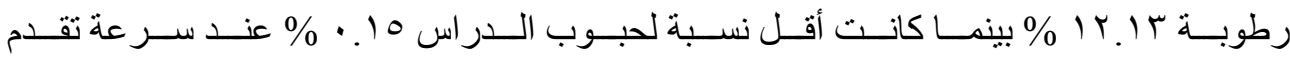

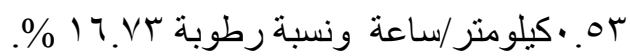

\footnotetext{
باحث أول بمعهد بحوث الهندسة الزر اعية ـ الدقى ـ الجيزة ـ مصر

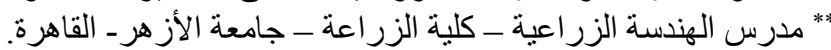

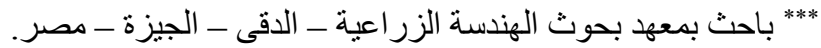




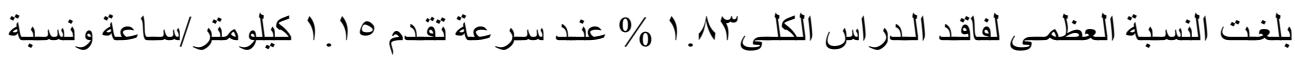

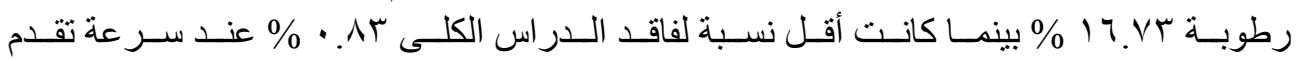

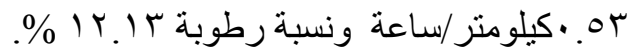

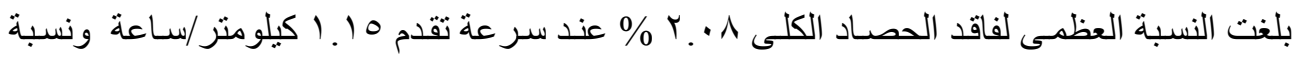

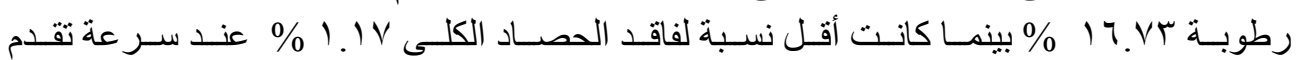

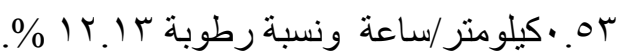

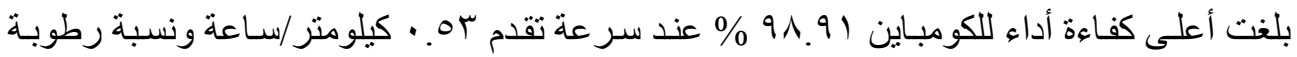

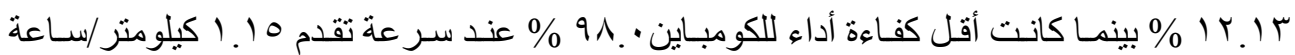

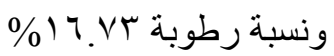

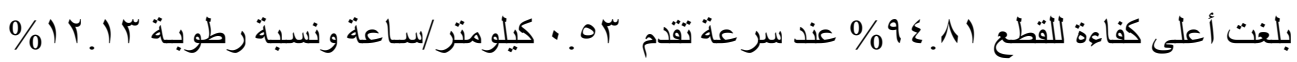

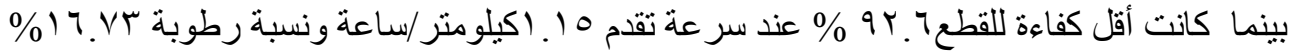

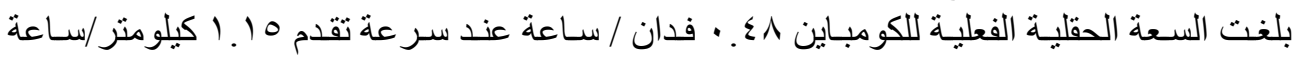

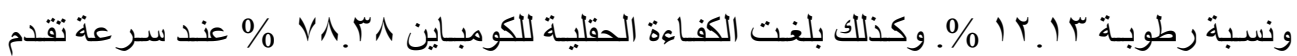

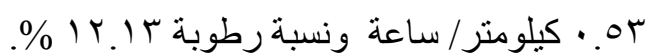

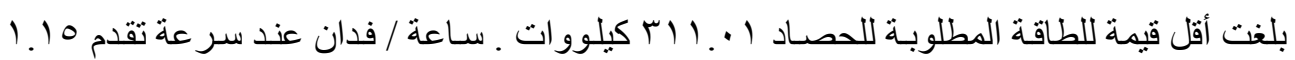

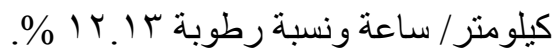

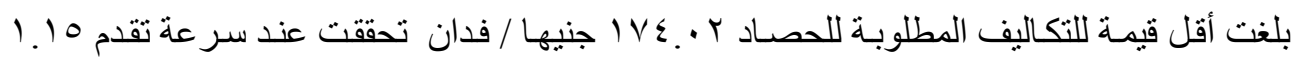

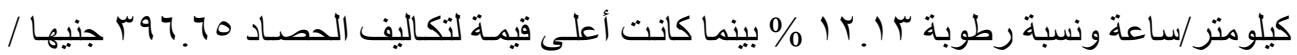

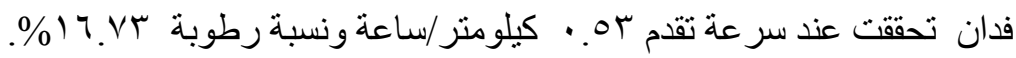

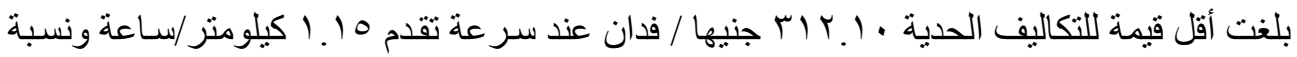

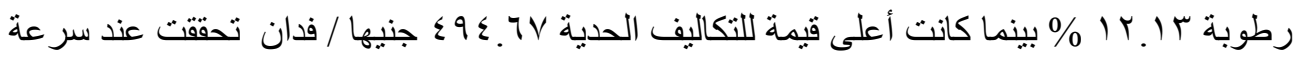

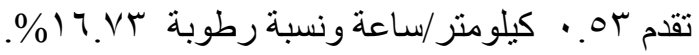

